\title{
Mixed Solid Device Based on Conducting Polymer Composite and Polymer Electrolyte
}

\author{
Silmara Neves* and Carla P. Fonseca \\ Laboratório de Caracterização e Aplicação de Materiais (LCAM), Unidade Acadêmica de Ciências Exatas e \\ Tecnológicas, Universidade São Francisco, 13251-900 Itatiba - SP, Brazil
}

\begin{abstract}
Filmes porosos de sílica sol-gel obtidos a partir de tetraetil ortosilicato (TEOS) foram utilizados como moldes para a polimerização eletroquímica da anilina. Foi investigado o comportamento redox e as capacidades de carga/descarga de uma bateria polimérica de lítio constituída pelo compósito polianilina-sílica, utilizado como catodo, e pelo eletrólito gel polimérico poli(dimetilsiloxano-coóxido de etileno). O compósito apresentou uma elevada capacidade inicial (140 mA h g-1) e uma capacidade reversível de $75 \mathrm{~mA} \mathrm{~h} \mathrm{~g}^{-1}$ após 100 ciclos de carga/descarga. O decréscimo na capacidade específica foi atribuído ao aumento da resistência de transferência de carga e à diminuição do coeficiente de difusão determinados pela espectroscopia de impedância eletroquímica.
\end{abstract}

Tetraethyl orthosilicate (TEOS) derived sol-gel porous films have been utilized as template for the electrochemical polymerization of aniline. Polyaniline-silica composites were obtained and the redox behavior and charge/discharge capacities of a lithium polymeric battery using poly (dimethylsiloxane- co-ethylene oxide) as gel polymeric electrolyte, were investigated. The composite presented a high initial capacity $\left(140 \mathrm{~mA} \mathrm{~h} \mathrm{~g}^{-1}\right)$ and a reversible capacity of $75 \mathrm{~mA} \mathrm{~h} \mathrm{~g}^{-1}$ after 100 charge/discharge cycles. The decrease in the specific capacity was attributed to an increase in charge transfer resistance and a decrease in the diffusion coefficient measured by electrochemical impedance spectroscopy.

Keywords: polyaniline, composites, solid polymer electrolyte, batteries

\section{Introduction}

Historically the interest in conducting polymers is based on its potential commercial applications, through the promise of a novel combination of lightweight, processibility and electrical conductivity. There was a great deal of initial excitement about conducting polymers as active materials in rechargeable batteries. Due to their low densities, it was thought that batteries with power densities much higher than those of the ordinary lead/acid battery could be readily obtained. Since charge on a polymer backbone is distributed over three or four repeat units, the charge capacity per unit weight for conducting polymers is marginally better than for that of metals.

Until recently, polyaniline (PAni) was the electroactive polymer most investigated for battery applications. ${ }^{1,2}$ Their first major commercial application has been the button cell batteries of Bridge-stone Seiko. ${ }^{3}$ The manufacturing cost for other conducting polymers except polyaniline is

\footnotetext{
* e-mail: silmara.neves@ saofrancisco.edu.br
}

expensive up to the present. The main characteristics of Li-PAni secondary batteries compared with conventional Li secondary batteries were the longer cyclic life, less selfdischarge rate, endurance to overdischarge, low manufacture cost, and the shape flexibility to making thin films. Since the specific capacity of Li-conducting polymer secondary batteries is small, these are used as back-up power source and for small electronic devices.

Many investigations have been concerned with the possibility of applying polyaniline to solid-state rechargeable lithium or Li-ion battery as a positive material. ${ }^{4-7}$ It was found that PAni/PEO- $\mathrm{LiClO}_{4}$ polymer electrolyte in a solid-state lithium battery exhibited a good electrochemical reversibility and cycleability at $50-80{ }^{\circ} \mathrm{C} .{ }^{5}$ Barther et al. ${ }^{8}$ prepared polyaniline composite with PEO-based polymer electrolyte as a binder for fabrication of a solid-state secondary lithium battery. Cyclic voltammetry and charge/discharge experiment were performed at $70{ }^{\circ} \mathrm{C}$. An improve of interfacial electrochemical characteristics and utilization ration of active material was observed. Recently, Chen et al. ${ }^{9}$ prepared a bilayer film by employing polyaniline powder 
as a positive active material and plasticized $\mathrm{PEO}-\mathrm{LiClO}_{4}$ as a binder and polymer electrolyte. It was found that the contacting surface area between PAni and polymer electrolyte was greatly improved by using polymer electrolyte as the binder. As a result, the discharge capacity was improved.

In this work, we report the use of a promising cathode material for rechargeable lithium batteries: a polyaniline composite obtained by template synthesis through the electrochemical polymerization of aniline in the heterogeneous void spaces of silica porous films. In previous works, ${ }^{10-13}$ we verified by several characterization techniques that electrochemical properties of polyaniline are improve in composite systems due to the apparent synergism between the host matrix and the polymer. The last works were realized in aqueous and organic medium. Now, to avoid liquid leak in the cell, we are proposing the use of a polymeric electrolyte, poly (dimethyl siloxaneco-ethylene oxide) - $\mathrm{P}(\mathrm{DMS}-c o-\mathrm{EO}) / \mathrm{LiClO}_{4}$, with the composite PAni-silica as cathode in the lithium polymeric battery.

\section{Experimental}

The electrochemical characteristics of polyaniline composite $\mid \mathrm{P}\left(\mathrm{DMS}\right.$-co-EO) $/ \mathrm{LiClO}_{4} \mid \mathrm{Li}$ system were determined with two electrodes. The working electrode consisted of an ITO|glass substrate on which the composite material was synthesized. The polymerization of PAni within the porous of silica films $/ \mathrm{ITO}^{14}$ was done in the potentiodynamic mode by cycling the potential from 0.10 to $0.80 \mathrm{~V}$ against $\mathrm{Ag} \mid \mathrm{AgCl}$. The deposition solution consisted of $1.0 \mathrm{~mol} \mathrm{~L}^{-1} \mathrm{HCl}$ and $1.0 \mathrm{~mol} \mathrm{~L}^{-1} \mathrm{NaCl}$ containing $0.1 \mathrm{~mol} \mathrm{~L}^{-1}$ of distilled aniline. The amount of polyaniline $(1.03 \mu \mathrm{g})$ was calculated from the deposition charge..$^{15}$

The polymer electrolyte was prepared by mixing $\mathrm{P}$ (DMS-co-EO) with $5.0 \%$ wt. $\mathrm{LiClO}_{4}$ in tetrahydrofuran (THF). This salt concentration was chosen because it was shown in previous work ${ }^{16}$ that it provided the best ionic conductance, electrochemical stability window and passivation layer. The electrolyte solution was placed on the composite film and a Capton spacer (30 mm thick) was used to prevent short-circuits and to maintain a fixed thickness of electrolyte during measurements. After drying the films, the PAni-silica $\left|\mathrm{P}(\mathrm{DMS}-\mathrm{co}-\mathrm{EO})-\mathrm{LiClO}_{4}\right| \mathrm{Li}$ system was stored in a dry box with an argon atmosphere.

Electrochemical measurements were made with an AUTOLAB - PGSTAT30 FRA. Impedance spectroscopy was done in the frequency range $10^{5}-10^{-2} \mathrm{~Hz}$ with an excitation signal of the $10 \mathrm{mV}$.

\section{Results and Discussion}

When the PAni-silica film and the gel polymer electrolyte layer prepared separately were combined to fabricate the cell, a good contact was obtained, as shown by the cyclic voltammogram of the PAni-silica | P(DMSco-EO)- $\mathrm{LiClO}_{4} \mid \mathrm{Li}$ system, Figure 1. As can be observed, the ionic conductivity ${ }^{16}$ of the electrolyte $\left(2.6 \times 10^{-4} \mathrm{~S} \mathrm{~cm}^{-1}\right)$ was sufficiently high to promote the doping and redox process in the PAni. The voltammetric peaks corresponded to the changes in the oxidation state of the polyaniline that were related to the amine and imine content ratio in the film. ${ }^{17}$ The capacitive profile is also verified due to the insulating characteristics of silica matrice. The intensity of current peaks and the coulombic efficiency $(\approx 100 \%)$ of the redox reaction of the PAni-silica composite indicated good electrochemical performance of the system.

The insert in Figure 1 shows the electrochemical stability window of the $\mathrm{P}\left(\mathrm{DMS}-\mathrm{co}\right.$-EO)- $\mathrm{LiClO}_{4}$ polymer electrolyte (approximately $5 \mathrm{~V}$ ) which was limited cathodically by pseudo-reversible lithium deposition. The pseudo-plateau between 1 and $0 \mathrm{~V}$ was attributed to salt reduction. The anodic limit is related to anion oxidation process followed by a possible polymeric degradation. ${ }^{18}$

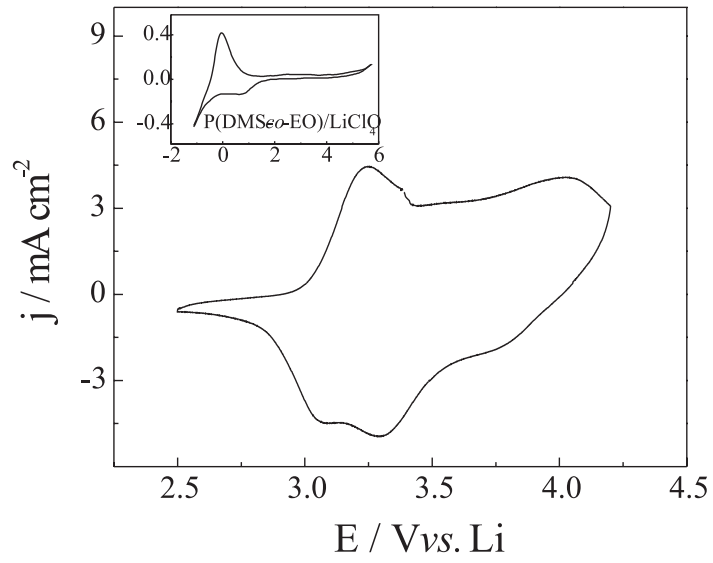

Figure 1. Steady state cyclic voltammogram of the PAnisilica|P(DMS-co-EO) $\mid \mathrm{Li}$ system, at $1 \mathrm{mV} \mathrm{s}^{-1}$. The inset shows the electrochemical stability window for the polymeric electrolyte at same scan rate.

The charge/discharge performance of the Li/ PAnisilica battery using $\mathrm{P}\left(\mathrm{DMS}-\mathrm{co}\right.$-EO)- $\mathrm{LiClO}_{4}$ gel polymeric electrolyte was investigated by the galvanostatic battery test at $1 \mu \mathrm{A} \mathrm{cm}^{-2}$, Figure 2 and 3 .

Figure 2 shows a typical charge/discharge curve of this system after the first and $100^{\text {th }} \mathrm{cycle}$. The initial open circuit potential was $3.35 \mathrm{~V}$ and the charging process was limited to $4.00 \mathrm{~V}$ cut-off potential in order to avoid the over oxidation of polyaniline. 


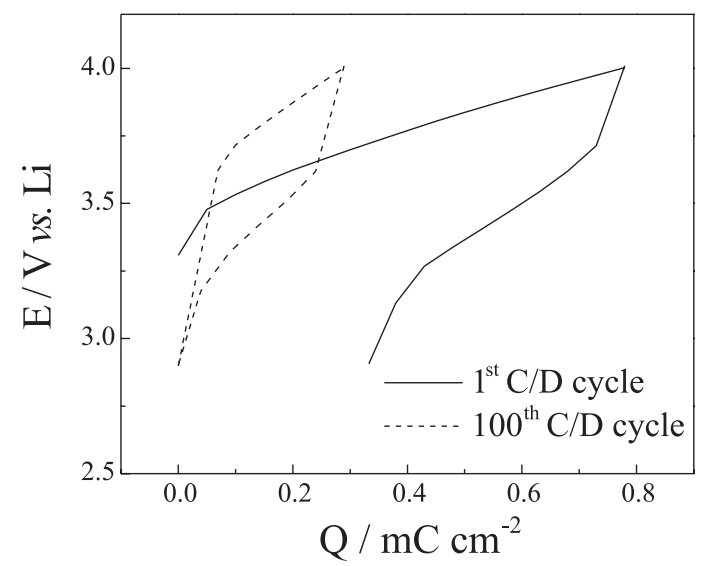

Figure 2. The first and $100^{\text {th }}$ charge/discharge cycle; current density of $1 \mu \mathrm{A} \mathrm{cm}^{-2}$.

In Figure 3 the capacity curves show that system delivered an initial charge capacity of $140 \mathrm{~mA} \mathrm{~h} \mathrm{~g}^{-1}$ and a discharge capacity of $127 \mathrm{~mA} \mathrm{~h} \mathrm{~g}^{-1}$, both based on the polymer mass. This difference probably reflected nonconditioning of the film. From the second cycle onwards, the reversibility of the electrode increased and was quite excellent after 25 cycles. These results demonstrated that the PAni-silica $\mid \mathrm{P}(\mathrm{DMS}-\mathrm{co}$-EO)-LiClO 4 | Li system had sufficient electrochemical stability and reversibility. However, the specific capacity gradually decreased to 75 $\mathrm{mA} \mathrm{h} \mathrm{g}^{-1}$ after 100 cycles. These results were considered promising because they were very similar to the results previously reported ${ }^{19-21}$ for thin oxide films and were better than those for conducting polymers obtained by chemical synthesis. ${ }^{9,22}$

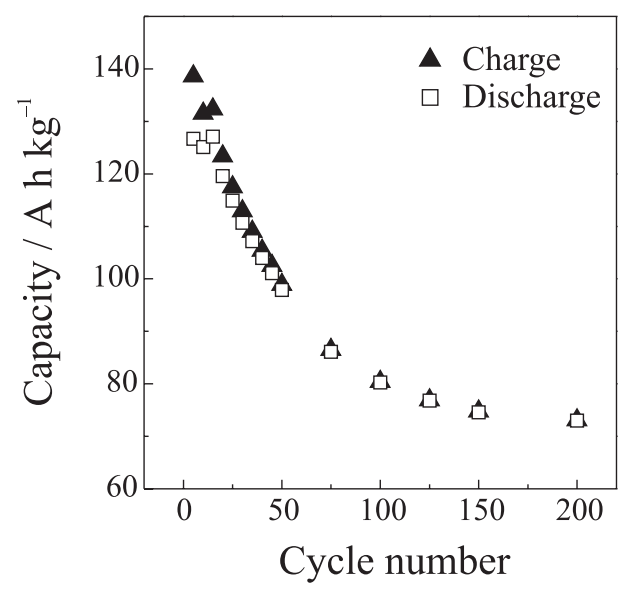

Figure 3. Dependence of the charge/discharge capacity on the number of cycles; current density of $1 \mu \mathrm{A} \mathrm{cm}^{-2}$.

To investigate the reason for the significant decay in capacity observed, a.c. impedance experiments were done and compared to the system after the $1^{\text {st }}$ and $100^{\text {th }}$ charge/ discharge cycles. The spectra were recorded at an open circuit voltage of approximately $3.3 \mathrm{~V} v$ s. Li, Figure 4.

Due to a larger pore size distribution in template host (silica), the polymer forms a continuous conducting network within the composite films but, a porous morphologies were still observed. ${ }^{23}$ The porous structure of the composites permits a contact with the gel electrolyte that penetrates the pores forming parallel ionic and electronic conduction paths. The interfacial reaction resistance could be determined from a curve-fitting analysis of the modified Randles equivalent circuit described in Figure 5, which includes this resistance as one of the components. Often in battery studies, the interfacial charge transfer resistance is in parallel with the double-layer capacitance $Q_{d l}$, which gives rise to a semicircle in the impedance plane at higher frequencies. The exact frequency range over which this semicircle occurs will depend on the values of the interfacial reaction resistance, $\theta\left(\theta=R T / n I_{0} F\right.$, where $n$ is the number of electrons transferred at the interface, $I_{0}$ is the exchange current density, $F$ is Faraday's constant, $R$ and $T$ are the ideal gas constant and the absolute temperature, respectively) and $Q_{d l}$, but it will often fall in the range of $1-10^{4} \mathrm{~Hz},{ }^{24}$ as observed in Figure 4. From this semicircle the charge transfer resistance $\left(R_{c t}\right)$ was estimated. The system impedance increased greatly after cycling, particularly the $\mathrm{R}_{\mathrm{ct}}$, which rose by a factor 5 to reach $100 \mathrm{k} \Omega \mathrm{cm}^{2}$ compared to $20 \mathrm{k} \Omega \mathrm{cm}^{2}$ determined after the first cycle.

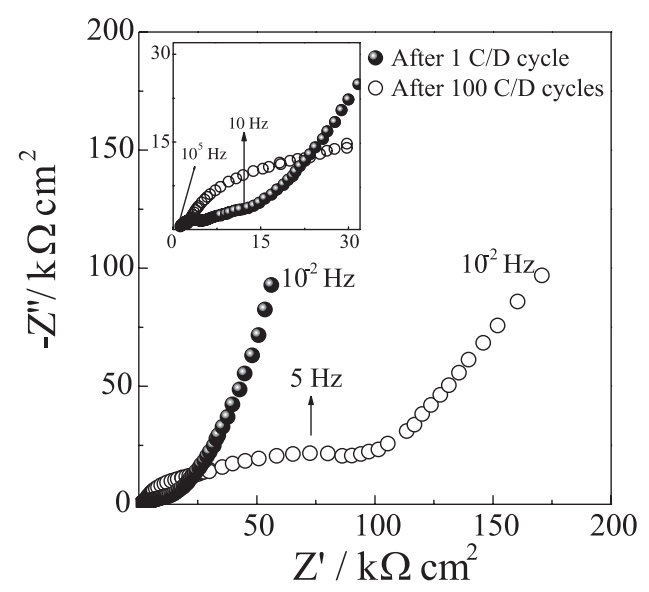

Figure 4. Nyquist diagram at the OCP potential $(3.35 \mathrm{~V})$ of the system after the first and $100^{\text {th }}$ charge/discharge cycles. The inset shows the high frequency range.

The diffusion coefficient (D) was calculated using a Randles modified equivalent circuit and equation 1, as described in Figure 5 and Ho et al. ${ }^{25}$, respectively,

$\mathrm{D}=l^{2} /\left(\mathrm{Q}_{1} \mathrm{~A}_{\mathrm{w}}\right)^{2}$ 
where $l$ is the film thickness, $\mathrm{Q}_{l}$ is the limit capacitance and $\mathrm{A}_{\mathrm{W}}=\sqrt{ } 2 / 2 \mathrm{y}_{0} \cdot \mathrm{Q}_{l}$ and $\mathrm{y}_{0}$ (system-dependent parameter) were determined by data fitting.

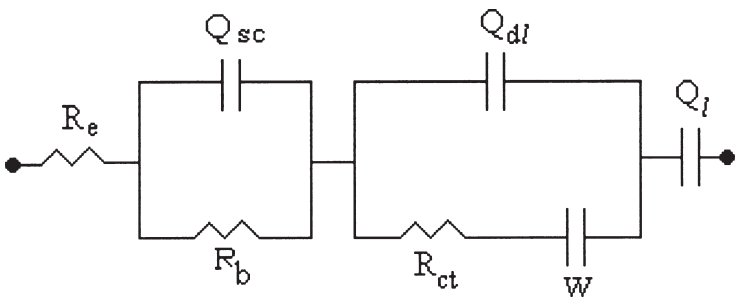

Figure 5. Equivalent circuit of the system after the first and $100^{\text {th }}$ charge/discharge cycles, where $\mathrm{R}_{\mathrm{e}}, \mathrm{R}_{\mathrm{b}}, \mathrm{R}_{\mathrm{ct}}$ are the electrolyte, bulk and charge transfer resistances, respectively. $\mathrm{Q}$ is the constant phase element, where $\mathrm{Q}_{\mathrm{sc}}, \mathrm{Q}_{\mathrm{dl}}$ and $\mathrm{Q}_{1}$ are related to space charge, double layer and limit capacitance, respectively. $\mathrm{W}$ is the Warburg impedance.

The diffusion coefficients were $2.8 \times 10^{-10}$ and $1.54 \mathrm{x}$ $10^{-11} \mathrm{~cm}^{2} \mathrm{~s}^{-1}$ for the solid device after the first and $100^{\text {th }}$ charge/discharge cycles, respectively.

These results were consistent with cycling behavior (Figure 2) and were main related to negative electrode. ${ }^{26}$ In some Li/PAni cells reported in literature ${ }^{27,28}$ the apparent cell capacity decrease due to an accumulation of dopant ions in the polymer: the amounts of charge corresponding to the difference in Coulombic efficiency between the positive and negative electrode remained in the positive electrode in each cycle. Thus, an apparent deterioration of the cell capacity during cycling caused by an excessive uptake of doping sites by dopant ions occur. Moreover, the chemical side reactions of lithium and electrolyte components, generally occur in organic liquid electrolyte systems. ${ }^{29,30}$ The side reaction products, which have poor ionic conductivity, accumulate at the interface of lithium with the gel electrolyte, and increase with the charge/ discharge cycles. As a result, the interfacial resistance increases and raises the total inner resistance of the system, thereby favouring the ohmic drop. With an increase in the ohmic drop, the practical operating voltage range narrows. So that the discharge capacity of the battery decreases with cycle number.

Other factors that contribute to decrease in specific capacity include polymer degradation at high anodic potentials and growth of the insulating polymer layer in the extreme cathodic limit. Some cross-linking reactions may have occurred along the polyaniline chain when the battery reached the anodic limit since the spatial restraint in the sol-gel silica matrix was imposed only by the nanopores. On the other hand, when potentials varied towards the formation of a poorly conducting phase, the thin dielectric polymer layer formatted in the current collector-composite interface blocked the electrode and made charging difficult.

\section{Conclusions}

These results confirmed that polyaniline composite obtained by the template approach could be used as a cathode adapted to polymer electrolyte in rechargeable lithium batteries. The composite showed a high initial capacity $\left(140 \mathrm{~mA} \mathrm{~h} \mathrm{~g}^{-1}\right)$ and a reversible capacity of 75 $\mathrm{mA} \mathrm{h} \mathrm{g}{ }^{-1}$ after 100 charge/discharge cycles. The decrease in the specific capacity was attributed to an increase in charge transfer resistance and a decrease in the diffusion coefficient as measured by electrochemical impedance spectroscopy. Compared to other conducting polymers and lithium transition metal oxides, the composite showed good electrochemical reversibility as a positively active material associated with a polymeric electrolyte.

Based on these results, we concluded that PAni-silica composite and $\mathrm{P}(\mathrm{DMS}-\mathrm{co}-\mathrm{EO})-\mathrm{LiClO}_{4}$ electrolyte provide potentially useful materials for polymeric microbatteries.

\section{Acknowledgements}

This work was supported by FAPESP (grant number 98/14756-8)

\section{References}

1. Chiang, J.C.; MacDiarmid, A.G.; Synth. Met. 1986, 13, 193.

2. Novák, P.; Müller, K;. Santhanam, K.S.V.; Haas, O.; Chem. Rev. 1997, 97, 207.

3. Nakajima, T.; Kawagoe, T.; Synth. Met. 1989, 28, C629.

4. MacDiarmid, A.G.; Yang, L.S.; Huang, W.S;. Humphery, B.D.; Synth. Met. 1987, 18, 393.

5. Yang, L.S.; Shan, Z.Q.; Liu, Y.D.; Solid-State Ionics 1990, 40/41, 967.

6. Yang, L.S.; Shan, Z.Q.;. Liu, Y.D.; J. Power Sources 1991, 34, 141.

7. Yang, L.S.; Shan, Z.Q.; Hou, P.M.; Chen, W.X.; Liu, L.; J. Power Sources 1993, 43/44, 499.

8. Barthet, C.; Guglielmi, M.; Baudry, P.; J. Electroanal. Chem. 1997, 431, 145.

9. Chen, W.; Xu, Z.; Yang, L.; J. Power Sources 2001, 102, 112.

10. Neves, S.; Polo Fonseca, C.; J. Power Sources 2002, 107, 13

11. Neves, S.; Torresi, S.C.; Zoppi, R. A.; Synth. Met. 1999, 101, 754.

12. Maia, D.J.; Zarbin, A.J.G.; Alves, O.L.; De Paoli, M.-A.; Neves, S.; Quim. Nova 2000, 23, 204.

13. Neves, S.; Fonseca, C. P.; Electrochem. Commun. 2001, 3, 36. 
14. Neves, S.; Fonseca, C.P.; Zoppi, R.A.; Torresi, S.C.; J. Solid State Electrochem. 2001, 5, 412.

15. Koryta, J.; Dvorák, J.; Kavan, L.; Principles of Electrochemistry, $2^{\text {nd }}$ ed., John Wiley \& Sons: Chichester, 1993, ch. 5.

16. Polo Fonseca, C.; Neves, S.; J. Power Sources 2002, 104, 85.

17. Snauwaert, P.; Lazzaroni, R.; Riga, J.; Verbist, J.; Gonbeau, D.; Electronic Properties of Conjugated Polymers III, Springer: Berlin, 1989, vol 9, pp. 301-304.

18. Tonge, J.S.; Shriver, D.F.; The Electrochemistry of Novel Materials, VCH: New York, 1993, ch. 5.

19. Striebel, K.A.; Deng, C.Z.; Wen, S.J.; Cairns, E.J.; J. Electrochem. Soc. 1996, 143, 1821.

20. West, K.; Vitins, G.; Koksbang, R.; Electrochim. Acta 2000 , 45, 3141.

21. Kim, H.T.; Kim, K.B.; Kim, S.W.; Park, J.K.; Electrochim. Acta 2000, 45, 4001.

22. Ryu, K.S.; Kim, K.M.; Kang, S.G.; Lee, G.J.; Chang, S.H.; Solid State Ionics 2000, 135, 229.

23. Neves, S.; Fonseca, C.P.; Zoppi, R.A.; Torresi, S.C.; J. Solid State Electrochem. 2001, 5, 412.
24. Macdonald, J.R., ed.; Impedance Spectroscopy: Emphasizing Solid Materials and Systems, John Wiley \& Sons: Chichester, 1987, ch. 4.

25. Ho, C.; Raistrick, I.D.; Huggins, R.A.; J. Electrochem. Soc. 1980, 127, 343.

26. Mizumoto, M.; Namba, M.; Nishimura, S.; Miyadera, H.; Koseki, M.; Kobayashi, Y.; Synth. Met. 1989, 28, C639.

27. Taguchi, S.; Tanaka, T.; J. Power Sources 1987, 20, 249.

28. Novák, P.; Müller, K.; Santhanam, K.S.V.; Haas, O.; Chem. Rev. 1997, 97, 207.

29. Barthet, C.; Guglielmi, M.; Baudry, P.; J. Electroanal. Chem. 1997, 431, 145.

30. Osaka, T.; Momma, T.; Ito, H.; Scrosati, B.; J. Power Sources 1997, 68, 392.

Received: July 21, 2003

Published on the web: May 10, 2004

FAPESP helped in meeting the publication costs of this article. 